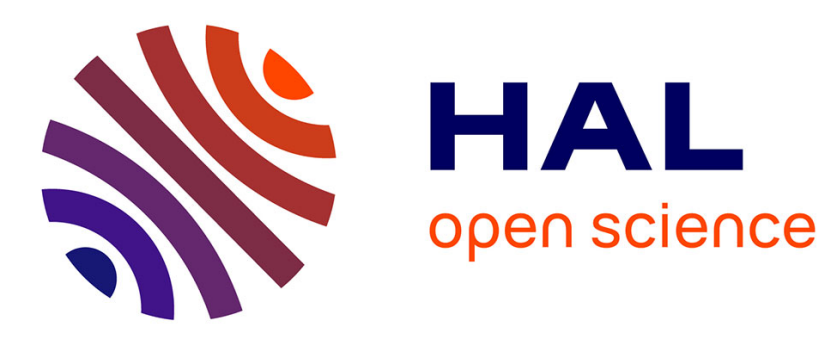

\title{
Book Lists and their meaning
}

\author{
Malcolm Walsby
}

\section{To cite this version:}

Malcolm Walsby. Book Lists and their meaning. Malcolm Walsby and Natasha Constantinidou (dir.), Documenting the Early Modern Book World: Inventories and Catalogues in Manuscript and Print, Leiden: Brill, 2013, p. 1-24, 2013. hal-01655869

\section{HAL Id: hal-01655869 \\ https://hal.science/hal-01655869}

Submitted on 5 Dec 2017

HAL is a multi-disciplinary open access archive for the deposit and dissemination of scientific research documents, whether they are published or not. The documents may come from teaching and research institutions in France or abroad, or from public or private research centers.
L'archive ouverte pluridisciplinaire HAL, est destinée au dépôt et à la diffusion de documents scientifiques de niveau recherche, publiés ou non, émanant des établissements d'enseignement et de recherche français ou étrangers, des laboratoires publics ou privés. 


\title{
BOOK LISTS AND THEIR MEANING
}

\author{
Malcolm Walsby
}

For the three centuries after the invention of printing the purchase of a book remained, for most of Europe's peoples, an unusual and memorable event. During this period some of Europe's most affluent citizens accumulated collections of very considerable size; but even here purchases were carefully considered and weighed against other forms of expenditure. Most collections were, in any case, much smaller. Even the largest institutional libraries numbered only a few thousand. ${ }^{1}$

It is no surprise that book owners took particular care of these collections. As they might with other prized possessions, furniture or expensive fabrics, books were frequently carefully listed, often after a collector's death or when a bookshop changed hands, but sometimes for the mere pride and pleasure of possession. ${ }^{2}$ Filed away in archives all over Europe, several thousand of these book lists, or lists containing books, have survived to this day. The great surprise is that these lists and catalogues have not been more systematically employed in bibliographical studies. Cultural historians certainly recognise the importance of books as material objects, and certain personal collections, particularly those of distinguished individuals, have been closely studied. But even in a field as particular as book history, there is some disconnection between the attention given to reading, as revealed by book ownership, and the attempts by bibliographers to document production, as revealed by records of surviving copies.

${ }^{1}$ For the early history of libraries see Andrew Pettegree, The Book in the Renaissance (London, Yale University Press, 2010). For England see the work undertaken by the Private Libraries in Renaissance England group: http://plre.folger.edu/ and the research project described in David Pearson's recent article 'The English Private Library in the Seventeenth Century', The Library, XIII (2012), pp. 379-399. I would like to thank Christine Bénévent, Flavia Bruni, Natasha Constantinidou and Andrew Pettegree for their comments on an early draft of this text.

2 See D. Raines, 'La biblioteca-museo patrizia e il suo capitale sociale-modelli illuministici veneziani e l'imitazione dei nuovi aggregati' in C. Furlan (ed.), Arte, storia, cultura e musica in Friuli nell'età del Tiepolo, atti del convegno internazionale di studi (Udine, 19-20 dicembre 1996) (Udine: Forum, 1997), pp. 63-84. 
Of course only a small proportion of books published in the fifteenth, sixteenth and seventeenth centuries survive today. Many are no doubt lost altogether. Yet the great national bibliographical projects, the English STC, the German VD 16 and the Italian Edit 16 are exclusively made up of these hardy survivors. ${ }^{3}$ Given the very variable survival rates for different types of book, it is unlikely these can represent the whole corpus of books actually produced. Some types of book will be markedly under-represented. In the circumstances, it seems perverse not to make more use of the multitudinous evidence of contemporary collecting, as revealed in surviving book lists and catalogues, to round out our picture of early modern book ownership and production.

In the years of research leading to the on-line publication in 2011 of the Universal Short Title Catalogue (USTC), the St Andrews book project team attempted always to remain mindful of the opportunities offered by these resources. The USTC already contains several thousand records for works that cannot be documented by surviving copies, but are nevertheless attested by a dependable contemporary record. In the summer of 2011 it was decided to devote our annual book conference to an exploration of these documents which, as it turned out, proved to be not only exceptionally rich, but also very diverse. This introductory essay sets the scene for the individual case studies that follow, laying out an outline typology for the very different sorts of lists and catalogues in which contemporaries recorded loved, disapproved, or valuable books. It also suggests how, and with what cautions, they may be used to examine the expanding world of book ownership and production.

\section{Organising and Listing}

The desire to organise was strong throughout the Renaissance. ${ }^{4}$ Through their rediscovery of earlier manuscripts and their new approach to the texts, Renaissance thinkers undermined the traditional mediaeval order. With the appearance of print, the quantity of different texts that

3 All are now available on line, though the simplest way of accessing them is probably now through the Universal Short Title Catalogue, where they may be searched together: http://www.ustc.ac.uk/.

4 A. Blair, Too Much to Know. Managing Scholarly Information Before the Modern Age (New Haven: Yale University Press, 2010) and N. Rhodes and J. Sawday (eds), The Renaissance Computer. Knowledge Technology in the First Age of Print, (London and New York: Routledge, 2000). 
circulated rose exponentially and created a cacophony of differing views. This was further complicated by the Reformation as religious divisions challenged one of the strongest sources of relatively consistent thinking that remained in Europe: the Catholic Church. Language itself was changing and the confusion that followed encouraged scholars to look for a new sense of order. ${ }^{5}$ The first two centuries of print saw the publication of a growing number of dictionaries that ordered and re-ordered the language, mostly following a strict alphabetical order. ${ }^{6}$ The prevalence of alphabetical ordering was one of the characteristics of the print world and offered a first semblance of order. The printing process placed a particular emphasis on each letter. Because it was necessary to cast letters separately, there was great interest in their design and in the creation of ornamental initials. Entire books were printed that dealt solely with the question of type and the proportions used for each letter. ${ }^{7}$ There was even discussion about how the alphabet could be changed. ${ }^{8}$ The alphabetical order was also present in all publications as part of the signatures that accompanied each quire of the volume. In other words, the traditional use of the 23 letter alphabet and, where necessary, its repetition acted as guarantors of the order of the book. The text was also accessed through an alphabetical index, which became an important feature of printed books. ${ }^{9}$ The alphabet was also used to order the contents of many book lists. In most of those analysed in this volume, the guiding principle was to order alphabetically by the author's first name, though this was by no means a consistent choice. In the 1612 catalogue of Scaliger's books, for instance, there was no alphabetical approach. ${ }^{10}$ In some instances, the

5 C. Demaizière 'Un besoin nouveau: ordonner le langage' in G.A. Pérouse (ed.) Ordre et désordre dans la civilisation de la Renaissance: actes du colloque, Nice, septembre 1993 (Saint-Étienne: Publications de l'Université de Saint-Étienne, 1996), pp. 139-147.

6 B. Quemada, Les dictionnaires du français moderne 1539-1863. Étude sur leur histoire, leurs types et leurs méthodes (Paris: Didier, 1967), p. 47. See also Martine Furno's numerous articles and her forthcoming work on Robert Estienne to be published by Droz in Geneva.

7 The two best known examples are probably: Geoffroy Tory's Champfleury auquel est contenu l'art et science de la deue et vraye proportion des lettres attiques (Paris, pour Geoffroy Tory et Gilles de Gourmont, 1529) FB 49486 and Christopher Plantin's Index sive specimen characterum Christophori Plantini (Antwerpen, Christophe Plantin, 1567) NB 25676.

8 A. Szabari 'Le faisable qui ne se fait pas. La fantaisie évangélique de l'écriture chez Honorat Rambaud' in G. Defaux (ed.) Lyon et l'illustration de la langue française à la Renaissance (Lyon: Presses de l'ENS, 2002), pp. 183-207.

9 On the reorganisation of the book see E.L. Eisenstein The Printing Press as an Agent of Change (Cambridge: Cambridge University Press, 1980) pp. 88-106 On indexes, see also H. Meschonnic, Des mots et des mondes. Dictionnaires, encyclopédies, grammaires, nomenclatures (Paris: Hatier, 1991).

10 Article 3: 'The Legacy of Scaliger in Leiden University Library Catalogues, 16o9-1716'. 
lists simply followed the layout of the books in the libary in which they were housed.11

Because of the great quantity of volumes published throughout Europe, the ordering of books posed specific problems. The output of the workshops offered a wide variety of languages and religious view points as well as publications with restricted networks of distribution. Creating lists was an important part of the process of bringing order to this vast and potentially incendiary array of printed matter. The author served society, not only by providing a reference resource, but by bringing a sense of order and stability. ${ }^{12}$

The urge to organise books resulted in the publication of volumes such as Conrad Gesner's Bibliotheca Universalis, Antoine du Verdier and La Croix du Maine's volumes on French works and Antonio Possevino's Bibliotheca selecta. ${ }^{13}$ All these are well known to scholars of the printed book and demonstrate well the different approaches that could be taken by contemporaries seeking to make sense of the sudden outpouring of texts. Whilst Conrad Gesner employed a thematic approach for his Bibliotheca, Du Verdier and La Croix du Maine chose to adopt a purely alphabetical order. Possevino's work was conceived as a response to Gesner and had a similarly thematic structure, presenting a Catholic postTridentine selection of works in juxtaposition to Gesner's Protestant bibliography. ${ }^{14}$ All four were selective in their choices of which books to include and, whatever their claims, none sought to be truly universal in

11 Sometimes this layout was described in detail: see, for instance, the 1530 probate inventory of Hélion Jouffroy's books: M. Desachy, Deux bibliophiles humanistes. Bibliothèques et manuscrits de Jean Jouffroy et d'Hélion Jouffroy (Paris: CNRS éditions, 2012), pp. $107-150$.

12 On this see the wider thinking in Umberto Eco's The Infinity of Lists (London: MacLehose, 2009) and J. Cléard 'Encyclopédie et encyclopédisme à la Renaissance' in A. Becq (ed.) L'Encyclopédisme, actes du colloque de Caen de 1987 (Paris: Klincksieck, 1991), pp. $57-67$.

13 C. Gesner, Bibliotheca universalis (Zurich: Christoph Froschauer, 1545) VD16 G 1698; La Croix du Maine, Premier volume de la bibliotheque de la Croix du Maine (Paris: Abel L'Angelier, 1584) FB 31761; Antoine du Verdier, La bibliothèque d'Antoine Du Verdier, contenant le catalogue de tous ceux qui ont escrit, ou traduit en françois (Lyon: Jean d'Ogerolles pour Barthélemy Honorat, 1585) FB 17852; A. Possevino, Bibliotheca selecta qua agitur de ratione studiorum in historia, in disciplinis, in salute omnium procuranda (Roma: ex typographia Apostolica Vaticana, 1593) Edit 1633809.

14 On the question of the organisation of knowledge and the works of Possevino and Gesner see H. Zedelmaier's Bibliotheca universalis und Bibliotheca selecta: Das Problem der Ordnung des gelehrten Wissens in der frühen Neuzeit (Cologne: Böhlau Verlag, 1992). See also L. Balsamo, 'How to doctor a bibliography: Antonio Possevino's practice' in G. Fragnito (ed.), Church, Censorship and Culture in Early Modern Italy (Cambridge: Cambridge University Press, 2001), pp. 50-78. 
their coverage. They also had dissimilar bibliographical approaches, with very different standards of description for each work presented. As such, the works were representative of the wide variations in bibliographical practice in the creation of Early Modern book lists. But these selfconsciously monumental attempts at surveying the corpus of printed works only represent a tiny proportion of the book lists created in this period. Most book lists were far more specific and modest in intention.

\section{Analysing Book Lists}

The smaller lists have attracted a certain amount of attention in the scholarly community. A number of these archival discoveries have been transcribed and published in articles and even separate volumes, but often with only limited analysis from the editor. Typically, little effort is made to identify the particular editions cited and the commentary that accompanies them is broadly descriptive rather than analytical. ${ }^{15}$ This is a frustrating use of a good source, though this does not mean that the analysis of lists is in anyway straightforward. From the very start, most historians understood some of their interpretative limitations. In his groundbreaking study of 500 library catalogues mostly dated between $175^{\circ}$ and 1780, Daniel Mornet noted the "précautions rigoureuses" that needed to be applied. In particular, he noted that one needed to differentiate between establishing that an individual owned a book and the idea that he might have read it. ${ }^{16}$ Following in his footsteps, more scholars have addressed the question of how to interpret the presence of a book in a collection or the motives for book ownership, but far fewer have looked critically at what might have been omitted in the process of compiling such a list. ${ }^{17}$ In order to pursue these issues, this introduction summarises the different types of book lists created in the first centuries of print before looking at the limitations of these lists and noting the importance of contextual information. We shall then conclude by outlining some of the problems faced when attempting to identify precise editions. In order to

15 This unfortunate tendency has even affected well-respected scholars such as Pierre Jourda. See his 'La bibliothèque d'un juge à Narbonne au début du XVIIe siècle' Bibliothèque d'Humanisme et Renaissance (1936) 420-428 or his 'La bibliothèque d'un régent calviniste (1577) in Mélanges d'histoire littéraire de la Renaissance offerts à Henri Chamard (Paris: Nizet, 1951), pp. 269-273.

16 D. Mornet, 'Les enseignements des bibliothèques privées (1750-1780)' Revue d'histoire littéraire de la France, XVII (1910), pp. 449-492, at pp. 451-2.

17 Pearson, 'English Private Library', at pp. 386-387. 
achieve this, we have drawn extensively, but not exclusively, on the articles included in this volume.

\section{Types of Book Lists}

The library of the humanist and diplomat Cristóbal de Salazar (died 1587) is known thanks to no fewer than 14 separate book lists. These lists vary in their nature, ranging from complete catalogues of Salazar's collection to more succinct enumerations of books recently bought. Thanks to this, it is possible to have an exceptionally detailed understanding of the Spaniard's library. ${ }^{18}$ In cases such as this one when there is more than one inventory that can be analysed, it is possible to resolve some of the problems connected to the specific circumstances of a book list's creation and the peculiarities of the different types of documents that have survived. But such cases are extremely rare. In most instances the historian has to rely on a single book list. Each type of book list has its own characteristics and necessitates a different approach by the scholar.

Probate inventories. Perhaps the most common type of book list we find today was created at a collector's death. Along with all the most valuable belongings, books were listed amongst the possessions of the deceased and, when particularly numerous, appraised by a local bookseller. These probate inventories are an extraordinarily useful resource for historians, though their quality, completeness and number varied considerably from one country to another. In England, the 1529 probate and mortuaries act that regulated the fees paid to ecclesiastical courts also required that a detailed record be made of the possessions of a recently deceased person. ${ }^{19}$ As with all Renaissance legislation, the act was undoubtedly implemented with varying degrees of consistency throughout the kingdom, but it did have enough impact to be of great aid to the book historian. ${ }^{20}$

18 The lists are presented in J.-M. Lasperas, 'La biblioteca de Cristóbal de Salazar, humanista y bibliófilo ejemplar', Criticón, 22 (1983), pp. 5-132.

19 On probate inventories and their limitations, see M. Overton et al, Production and Consumption in English Households, 1600-1750 (London: Routledge, 2004), at pp. 13-14. R.J. Fehrenbach and E.S. Leedham-Green in the introduction to the first volume of their Private Libraries in Renaissance England. A Collection and Catalogue of Tudor and Early Stuart Book-Lists (Binghamton (N.Y.): Medieval and Renaissance Texts and Studies, 1992) refer to a slightly earlier statute of 1521 (I, Xvi).

20 See the continuing Private Libraries in Renaissance England project housed by the Folger Shakespeare library in Washington D.C. The database is available on-line at http:// plre.folger.edu. 
The careful appraisals led to an increase in the number of book lists included in probate inventories, especially in the sixteenth century when the comparative value of books was still relatively high. In contrast, in France, such inventories were only drawn up in specific circumstances. Typically, it was done at the request of one of the inheritors of the recently deceased individual or his creditors, when the main beneficiary was under-age or in cases where there was no obvious heir. As a result, the majority of successions did not require a full appraisal of belongings. ${ }^{21}$ The same was true in other regions of Europe. In Mantua, for instance, such inventories were usually drawn up when the normal heirs were either too young to dispose of them or when they were abroad. ${ }^{22}$

Booktrade lists. Some of the most substantial book lists to be found in probate inventories were drawn up after the death of members of the book trade. The books owned by printers, booksellers and bookbinders were their prized commercial assets and as such attracted far more interest from assessors than the smaller collections of private individuals. Such lists are particularly useful as they enable us to evaluate stocks and their resale price as estimated by the booksellers called in to give a valuation. But these are not the only lists that inform us of the holdings of members of the book trade. Even in the first decades of print, printers and booksellers published lists of their books as a way of advertising their holdings. We know, for instance, of a number of publishers' catalogues of the incunabula era, though these are mainly preserved in German-speaking areas. ${ }^{23}$ Members of the book trade also often kept manuscript registers as a means gauging sales and of stock taking. The Plantin Moretus Museum in Antwerp holds a substantial series of such registers that details all the sales of the Plantin from the sixteenth century onwards. ${ }^{24}$ Such lists are

21 See the remarks made in J.-L. Viret Valeurs et pouvoir. La reproduction familiale et sociale en Ile-de-France. Écouen et Villiers-le-Bel (1560-1685) (Paris: Presses de l'Université Paris-Sorbonne, 2004).

22 G. Rebecchini, Private Collectors in Mantua: 1500-1630 (Rome: Ed. di Storia e letteratura, 2002) p. 21. This also seems to have been the case elsewhere in Italy: D. Thornton, The Scholar in his Study. Ownership and Experience in Renaissance Italy (New Haven \& London: Yale University Press, 1997), pp. 15-17.

23 C. Coppens, 'A Census of Printers' and Booksellers' Catalogues up to 16oo: Some Provisional Conclusions', The Papers of the Bibliographical Society of America, 102 (2008), pp. 557-565. The classic study is G. Pollard \& A. Ehrman, The Distribution of Books by Catalogue from the Invention of Printing to A.D. 180o, Based on Material in the Broxbourne Library (Cambridge: Roxburghe club, 1965). A revised edition of this work is currently being prepared for the Bibliographical Society by Giles Mandelbrote.

24 See the analysis of Leon Voet in his The Golden Compasses: a History and Evaluation of the Printing and Publishing Activities of the Officina Plantiniana at Antwerp (Amsterdam: 
particularly interesting as they tell us a lot about the economics of the book trade. Sometimes these lists were also drawn up by prospective owners who wished to monitor their orders or, in the case of wealthy collectors, by those who did the purchasing for them so that they could justify their expenses and obtain reimbursement. This was the case for the books ordered for Catherine of Austria studied in this volume. ${ }^{25}$

Sales catalogues. The death of the owner of a library could also result in the public sale of his volumes. As the size of collections rose, so it became more and more common to have inventories drawn up and published in order to publicise the event and attract interest. These sales catalogues began to appear at the end of the sixteenth century and became commonplace in the second half of the seventeenth century. ${ }^{26}$ The large number of catalogues printed bears witness to the vibrancy of the second-hand book market and underlines the importance of lists to the book trade. ${ }^{27}$ In this volume, such sources are represented through the analysis of Norwegian juridical books and in the study of the Heinsius sales catalogue and its use as an early source of bibliographical information. ${ }^{28}$ The information in these lists was sometimes similar to that included in the probate inventory: both are principally concerned with the financial value of an item. The sales catalogue of the books of the duke of Croy, printed in 1614 in Brussels, showed just how close this relationship could be. In this case the printer, Rutger Velpius, simply replicated the contents of the probate inventory. ${ }^{29}$ For most catalogues, the presentation of the bibliographical information could vary substantially depending, notably, on the type of collection being sold. ${ }^{30}$

Vangendt \& Co; London: Routledge \& Kegan Paul; New York: Abner Schram, 1969-1972) volume II, chapters 15 to 19 .

25 Article 4: 'Books Fit for a Portuguese Queen: The Lost Library of Catherine of Austria and the Milan Connection (1540)'.

26 On this see Pollard and Ehrman, The Distribution of Books by Catalogue and, more recently, A. Charon \& É. Parinet, Les ventes de livres et leurs catalogues, XVIIe-XXe siècle (Paris: École des Chartes, 2000).

27 The importance of the trade in second-hand books is underlined in M. Yeo, The Acquisition of Books by Chetham's Library, 1655-1700 (Leiden: Brill, 2011), pp. 81-3.

28 For more the bibliographical use of sales catalogues see also the analysis of Michael Suarez, 'English Book Sale Catalogues as Bibliographical Evidence: Methodological Considerations Illustrated by a Case Study in the Provenance and Distribution of Dodsley's Collection of Poems', The Library, 21 (1999), pp. 322-339.

29 C. Coppens, 'A Post-Mortem Inventory Turned Into a Sales Catalogue: A Screening of the Auction Catalogue of the Library of Charles, Duke of Croy, Brussels 1614' Quaerendo, 38 (2008), pp. 359-380, at p. 361.

30 C. Rabier, 'Posséder les savoirs: les catalogues de vente des bibliothèques des chirurgiens français et britanniques $(1760-1830)$ ' in V. Millot, P. Minard and M. Porret (eds) La 
Private catalogues. The lists published by booksellers and printers were, inevitably, a source of commercial pride as they demonstrated the quantity and quality of the texts that they stocked. In this, they resembled private lists that proudly enumerated the riches to be found in a library. This was true of shared libraries, such as those put together by religious houses, or educational establishments. In these cases, the lists had a functional value: they indicated to potential readers which texts were available to them and, sometimes, where they were located. For individual private owners, knowing which books they possessed would have been less of an issue as they generally had fewer volumes and the collector would have a better knowledge of his own library. This type of catalogue was, therefore, often more an attempt to record these riches and to demonstrate to visitors the breadth and depth of the collection. However, it is worth noting that the emphasis on sharing knowledge the early modern intellectual culture meant that private libraries were frequently open to others who wished to use them. ${ }^{31}$

Censorship. Such sharing was not without risk. In an age of religious discord, the ownership of forbidden books was a serious matter. For booksellers, bookbinders and printers it could lead to the loss of their stock, which could be seized and destroyed and result in financial ruin. The discovery of censored texts could also discredit the business in the eyes of the religious authorities and lead to the loss of vital lucrative contracts or privileges that had been obtained from religious establishments. In some cases, the damage was even greater: booksellers or printers found to have prohibited material could be put on trial, condemned and executed. ${ }^{32}$ For private individuals there were also risks, and not just in moments of religious fervour during which the possession of unorthodox religious books could be used as proof to condemn its owner. In such a climate it was essential to know what constituted a forbidden book. It required the publication of lists of censored titles, authors and printers, even though such lists were inevitably also an inadvertent way of advertising the books'

grande chevauchée: faire de l'histoire avec Daniel Roche (Geneva: Droz, 2011), pp. 403-17, at pp. $405^{-6 .}$.

31 See for instance the case of Cardinal Bessarion's books: L. Labowsky, Bessarion's Library and the Biblioteca Marciana (Sussidi Eruditi, 31; Rome: Edizioni do storia e letteratura, 1979) and J. Monfasani, Bessarion Scholasticus: A Study of Cardinal Bessarion's Latin Library (Turnhout: Brepols. 2012).

32 See the different experiences discussed in M. Walsby 'Printer mobility in sixteenthcentury France' in B. Rial Costas (ed.) Print Culture and Provincial Cities in Early Modern Europe: A Contribution to the History of Printing and the Book Trade in Small European and Spanish Cities (Leiden: Brill, 2012), pp. 249-268, at pp. 255-6. 
contents. In order to police the sale and resale of such volumes, it became obligatory for booksellers and printers in France to draw up a list of the contents of their stores. ${ }^{33}$ In some countries, this desire to control the nature and contents of volumes went even further. The establishment of the Congregation of the Index in Rome, led to a vast survey that sought to draw up lists initially of all prohibited books then, later, of all books held by members of the Catholic Church be they lowly priests, monks or friars or important figures in the Church. ${ }^{34}$ The religious divide was therefore the source of multiple lists of both private and public libraries.

Autobibliographies. A much rarer, but most intriguing type of book list is presented in the study undertaken by Jürgen Beyer and Leigh Penman. ${ }^{35}$ In their article they present the concept of autobibliographies, that is, bibliographies published by the authors themselves. This interesting phenomenon looks at a very particular type of book list: one in which the editorial choices of what appears and what does not appear on the list are the result of a conscious effort by the author to shape his image through an enumeration of his writings and/or editions. In such circumstances, the issues at stake are complex and require a particularly close examination of the context in which the list was created.

These various classes of list allow the reconstruction of lost or dispersed libraries. ${ }^{36}$ They help us understand patterns of ownership. But they are not always dry enumerations of authors and titles; they also often contained valuable additional information. This extra material is particularly helpful for understanding various aspects of the early modern book trade. They sometimes provide data on cost, retail pricing, second hand values, binding and library practice. Furthermore, they also provide what can be the only indication of the existence of an edition and as such are extremely important to our understanding of the early modern book world. Taken together, the lists document many thousands of titles and editions that have now disappeared. This is particular interesting in the context of

33 See the clauses of the edict of Châteaubriant of 27 June 1551 published as Edict touchant la congnoissance, jurisdiction et jugement des proces des lutheriens et heretiques (Paris: Jean Dallier and Jean André, 1551) FB 25315 and following editions.

34 The articles of Flavia Bruni and Andrea Ottone in this volume analyse lists produced for the Congregation.

35 Article 7: 'Printed Autobibliographies from the Sixteenth and Seventeenth Centuries'.

36 The library of the founder of the Accademia dei Lincei Federico Cesi, dispersed after his death and partially even lost on a shipwreck, can be virtually reconstructed on the basis of two manuscript inventories of the seventeenth century: see M.T. Biagetti, 'Fisionomia scientifica e valore bibliografico della raccolta libraria di Federico Cesi' in F. Sabba (ed.), Le biblioteche private come paradigma bibliografico (Roma: Bulzoni, 2008), pp. 97-106. 
developing the Universal Short Title Catalogue. Whenever possible, the project team has sought to identify and provide bibliographical data on books that are no longer extant. For instance, as part of the work on French vernacular books undertaken by the project, the large volumes of La Croix du Maine and Antoine du Verdier were compared to the surviving corpus of fifteenth- and sixteenth-century books. Any unknown editions that were discovered thanks to this process were added to the bibliography when the data provided was deemed to be robust. ${ }^{37} \mathrm{Of}$ course, this process is not without dangers, as we shall see when we discuss the problem of identifying editions from book lists. But there are other caveats that need to be borne in mind when analysing or using the information provided by such lists.

\section{Limitations of Book Lists}

The most important issue for the scholar to come to terms with when working with book lists is determining what works may not have been included in the document as a matter of course. ${ }^{38}$ If it is vital to be aware that a given book list does not always contain every book in an individual's possession, it is possible to identify types of volumes that were routinely omitted from early modern documents.

Ephemera. Short brochures, printed ordinances and single sheet items were generally considered to be of little economic or long term intellectual value. This would have influenced the manner in which printers' and booksellers' holdings as well as private libraries were listed. When included, such pieces were often not enumerated; rather they were gathered together and described in generic fashion. It is not rare to find entries that simply state: "six small books some in French and some in Latin" or "53 small volumes of books in French of various sorts" without the slightest clue as to the titles included or even the general subject matter. ${ }^{39}$

37 See A. Pettegree, M. Walsby \& A. Wilkinson, French Vernacular Books. A Bibliography of Books Published in the French Language before 1601 (Leiden: Brill, 2007) and, more particularly, the article written by Sandy Wilkinson: 'Lost Books Printed in French before 1601', The Library, 10 (2009), pp. 188-205.

38 See, for instance, the volumes now known to have been in Nicolò III d'Este's collection but not included in the inventory of the library in 1436: A. Quondam, 'Le biblioteche della corte estense' in A. Quondam (ed.), Il libro a corte (Roma: Bulzoni, 1994), pp. 14-16.

39 These examples are respectively taken from R. Doucet, Les bibliothèques parisiennes au XVIe siècle (Paris: A. \& J. Picard, 1956), p. 11 and M. Connat \& J. Mégret 'Inventaire de la bibliothèque des Du Prat' Bibliothèque d'Humanisme et Renaissance, (1943), pp. 72-128, at p. 119. 
It is noticeable how few ephemeral pieces are to be found in book lists, whatever their genre. The manner in which books of little value were dismissed or excluded from most lists is demonstrated by the inventory of the sixteenth-century Krakow bookbinder Maciej Przywilcki when a collection of 14 outdated books were simply dismissed as being "old rubbish". 40 The perceived quality and importance of the texts printed in ephemeral formats was undoubtedly also a reason why some authors did not include such works in their own autobibliographies. This was probably what encouraged the German theological scholar August Pfeiffer to omit his occasional poetry from his own bibliography of the texts he had written. ${ }^{41}$

Pamphlets would have often fallen into this category of unrecorded ephemera. One would either have entries with unhelpful titles such as "Bundells of pamphlets in quarto" or nothing at all. As is pointed out by Joad Raymond for English books, in such cases the items taken separately were rarely worth more than one or two pennies and, therefore, would rarely be identified separately. ${ }^{42}$ The intellectual disdain with which pamphlets were held by most scholars of the sixteenth and seventeenth centuries was an additional reason why they could be excluded. The founder of the Bodleian library certainly thought that they were not worthy of preservation for future generations. ${ }^{43}$ Even an avid collector of such items such as Pierre de l'Estoile could describe pamphlets as portraying "la fureur et malice du temps" and accuse them of being a symptom of the "maladie du siècle, qui est la passion et la médisance". ${ }^{44}$ Whatever the perceived intellectual value of the texts, the content of the pamphlet could lead to its omission for another reason: the fear of condemnation by an ecclesiastical or civil authority, or in other words, because of censorship.

Censorship. Most of the lists compiled in the Early Modern period would not have included volumes that were liable to attract the attention

\footnotetext{
40 Article 11: 'The Book Inventory of the Sixteenth-Century Krakow Bookbinder, Maciej Przywilcki'.

41 Article 7: 'Printed Autobibliographies from the Sixteenth and Seventeenth Centuries'.

$42 \mathrm{~J}$. Raymond, Pamphlets and Pamphleteering in Early Modern Britain (Cambridge: Cambridge University Press, 2003), p. 4.

43 As well as Thomas Bodley's remark see the perceived link between pamphlets and slander or scurrility noted in Raymond, Pamphlets and Pamphleteering, at respectively pp. 5 and 8 .

44 The quotes are taken from Pierre de l'Estoile's journal as cited in G. Schrenck, 'Jeu et théorie du pamphlet dans le Journal du règne de Henri III (1574-1589) de Pierre de L'Estoile' in Traditions polémiques (Paris: École normale supérieure de jeunes filles, 1984), pp. 69-79, at p. 75 .
} 
of the censors. The catalogue of a private library drawn up by or for its owner might purposefully exclude works considered to be heretical or too licentious by the authorities. ${ }^{45}$ This would have been especially true for large libraries when catalogues were routinely used for identifying the ownership of titles not just by the collector himself, but also by other potential users. ${ }^{46} \mathrm{~A}$ post-mortem valuation of a collection might also exclude such volumes on the grounds that it would not be possible to sell them on. ${ }^{47}$ This effectively rendered them worthless and, therefore, they did not need to be enumerated. In other cases sales data did include some works deemed to be unorthodox, probably because the client was sufficiently powerful that the vendor felt safe under their protection. This was certainly the case for the book list presented by Kevin Stevens in his study of the items purveyed to the queen of Portugal, Catherine of Austria. In his study of the list created by the intermediary she had appointed, he demonstrates that she bought works banned both by Charles V and by the Papal index. ${ }^{48}$

Booksellers were well aware of the books that were supposed to be banned, but for which there was a market. Where necessary, they would resort to many different stratagems in order to by-pass controls. One ruse is particularly relevant to the analysis of book lists: the dissimulation of banned editions within volumes that also contained titles that had escaped censorship. By listing only the first title in the volume, the bookseller could hope to avoid detection-though, inevitably, it was a subterfuge that the authorities soon identified. The instructions given to port officials in the New World warned them to look out for this specific problem, noting that often "en un mesmo cuerpo vienen dos o tres libros encuadernados, y suele acontecer que el primero es bueno y los demás

45 Forbidden books were often kept apart from the rest of the library and, as a consequence, their registration could result in a separate list: this is the case of the forbidden section of the library of Johannes Faber, described in G. Miggiano, 'Fra politica e scienza: la biblioteca di Johannes Faber Linceo' in F. Sabba (ed.), Le biblioteche private come paradigma bibliografico (Roma: Bulzoni, 2008), pp. 107-153, at p. 122.

46 On this see the discussion of access to private collections suggested in C. Coppens, 'Et amicorum: not just for friends' in D. Sacré \& J. Papy (eds), Syntagmatia: Essays on NeoLatin Literature in Honour of Monique Mund-Dopchie and Gilbert Tournoy (Leuven: Leuven University Press, 2009), pp. 9-17.

${ }^{47}$ It is interesting, for instance, that the book collection of the Calvinist regent discussed by Pierre Jourda ('La bibliothèque d'un régent calviniste') contained no books by Calvin.

48 Article 4: 'Books Fit for a Portuguese Queen: The Lost Library of Catherine of Austria and the Milan Connection (1540)'. 
no". ${ }^{49}$ Such contrived miscellanies of diverse items bound together in a single volume also pose wider problems in the context of the analysis of book lists.

Books bound with other books. Very often the purpose of the inventory was to appraise volumes rather than describe precisely the texts they contained. As a result, it was easy for composite volumes containing a number of different editions that had been bound together by the owner to be described by simply indicating the first work present in the volume. Though in some lists a lot of care was taken to list all items, this was the exception rather than the rule. ${ }^{50}$ This difficulty has been noted, for instance, in the entries made into Norwegian auction catalogues. ${ }^{51}$ As a result, a large number of works may go unrecorded. Furthermore, because of the cost involved in the binding of books, it is common with early modern volumes to find texts that bear no relation to each other in the same binding. The omission of these editions was not necessarily the result of a conscious decision by the compiler. That it was all too easy simply not to notice that there was another text (or a number of other texts) bound behind the first text is demonstrated by the conflation of two different editions by François de Meyronnes in one of the book inventories compiled for the Roman Congregation of the Index. ${ }^{52}$

Multisite collections. An even greater and more common problem is lists that, though perhaps complete with regard to the books they were attempting to describe, only present part of a collection. Large collections in particular might necessitate the analysis of lists that covered a number of different locations in which an individual kept his books. Typically, this might involve the separate description of works used in the course of the owner's career (judicial books for example) and those used mainly for recreational reading. ${ }^{53}$ Furthermore, the existence of a second or third library

49 Instructions given in the 1570 s quoted in C. Val Julián, 'Surveiller et punir le livre en Nouvelle-Espagne au XVIe siècle' in D. de Courcelles (ed.), Le pouvoir des livres à la Renaissance: actes de la journée d'étude organisée par l'École nationale des Chartes et le Centre de recherche sur l'Espagne des XVIe et XVIIe siècles, Paris, 15 mai 1997 (Paris: École des Chartes, 1998), pp. 93-113, at p. 103.

50 The Parisian printer-bookseller Denis Duval did this by introducing the word « una » after an item: J. Delatour, Une bibliothèque humaniste au temps des guerres de religion. Les livres de Claude Dupuy (Villeurbanne: ENSSIB \& École des Chartes, 1998), p. 108.

${ }^{51}$ G. Dahl, "The Market for Books in Early Modern Norway: The Case of Juridical Literature'.

52 See the analysis of this instance in Flavia Bruni's study in this volume.

53 See Article 5 'The Library of the Breton Jurist and Historian Bertrand d'Argentré in $1582^{\prime}$. 
may not be made explicit in the document that has survived and may induce the scholar into erroneously thinking that the list he has identified enumerates the entirety of the books in the collection. The book lists of Baldassare Castiglione provide an interesting instance of this phenomenon. When Castiglione died in Toledo in 1529, officials compiled an inventory of the books he had left in Mantua before his departure for Spain in 1524. It was only in February 1530 when his belongings were repatriated from Toledo that the remainder of his books, including those he had originally taken with him and those that he had later acquired abroad, were finally appraised in a separate book list. ${ }^{54}$

The libraries of Louis de Rouvroy, duke of Saint-Simon are a particularly extreme example of this problem. The best known list of his books is the catalogue of the duke's books that were auctioned off in Paris a few months after his death on 2 March $1755 .{ }^{55}$ This sales catalogue contains some 1099 entries, but this does not represent the entirety of his collection. Far from being the only list of Saint-Simon's books, there were, in fact, a further five separate manuscript inventories that detailed the possessions of the duke. And each of them contained a partial list of the books he owned. In order to have a better understanding of his collection, it is necessary to analyse and compare all six lists. ${ }^{56}$ In this case we know of all six lists, but it is easy to imagine that for many owners the extant book list might, in fact, have only been one of a series of which none other has survived.

Such difficulties are echoed by Gina Dahl in her study of the juridical books to be found in Norwegian auction catalogues. She notes that many books never made it into the catalogues even if they appeared to advertise the sale of all the volumes owned by a given individual. Instead, a number of them were given away, kept by the family or sold off separately from the main part of the collection. ${ }^{57}$ Kasper van Ommen's analysis of the catalogues of Scaliger's books warns us not to expect that contemporary instructions were carried out the letter. He demonstrates that even when a bequest purported to contain the entirety of his oriental collection, in reality some relevant titles had been removed or were excluded and sold

\footnotetext{
54 Rebecchini, Private Collectors in Mantua, p. 116.

55 R. Davidts, Catalogue des livres de feu M. le duc de Saint-Simon, dont la vente se fera en détail lundi 11 août 1755 et jours suivants, rue de Grenelle, vis-à-vis de l'abbaye de Pantemont (Paris, 1755).

56 This has been done by Philippe Hourcade in his La Bibliothèque du duc de SaintSimon et son cabinet de manuscrits (1693-1756) (Paris: Éditions Classiques Garnier, 2010).

57 Article 8: 'The Market for Books in Early Modern Norway: The Case of Juridical Literature'.
} 
separately. As a result, the library catalogue which should have listed all Scaliger's oriental books was in this respect incomplete. ${ }^{58}$

Prices. Evaluating the composition of a library working only from partial surviving inventories is not the only issue faced by scholars. One of the most common pieces of additional data provided by book lists such as probate inventories and sales catalogues is a price. But such information must come with a warning: the nature of the list shapes the interpretation that should be placed on such price data. In probate inventories, for instance, appraisers were not looking at the original or bookseller value of the book but how much that volume was worth. Roger Doucet has suggested that there was little difference between the prices given in the inventories and genuine resale prices to be found elsewhere. ${ }^{59}$ But this is not borne out in all studies. The differences in the valuation of a collection could be quite marked. The sixteenth-century Lyon bookseller Étienne Michel certainly had a more inflated view of the value of his books than did his assessors and analysis of some of the figures given in the inventory of his warehouse compared to contemporary prices show important differences. ${ }^{60}$

This highlights that in most cases, and notably in the ones examined in Doucet's study, such a discussion misses the main point. Assessors were considering the book as an object as much as an edition. Just as is the case today, the state of a book, its provenance and condition could all change its value. In other words, prices were copy specific. The most important price differential was undoubtedly a result of the volume's binding. ${ }^{61}$ In the inventory of the books of Antoine du Prat, drawn up in 1557-8, some entries only gave information about the bindings and nothing on the books' contents. ${ }^{62}$ The valuation of the books in the workshop of the Krakow bookseller, Maciej Przywilcki offers some precise examples of the possible price differential. As Justyna Kiliańczyk-Zięba demonstrates,

58 Article 3: 'The Legacy of Scaliger in Leiden University Library Catalogues, 16o9-1716'.

59 Doucet, Bibliothèques parisiennes, pp. $72-3$. The author does not provide any proof for this assertion (and there is no accompanying footnote).

60 I. Maclean, 'Murder, Debt and Retribution in the Italico-Franco-Spanish Book Trade: the Beraud-Michel-Ruiz affair, 1586-91' in R. Myers, M. Harris and G. Mandelbrote (eds) Fairs, Markets and the Itinerant Book Trade (London: Oak Knoll Press and the British Library, 2007), pp. 61-106, at pp. 71-2.

61 The Procès-verbal of the inventory of the library of Pontus de Tyard drawn up in 1638 made this clear in the preamble noting that the valuations were done "selon les raretés, impress[ions] et relieures desditz livres" see S.F. Baridon, Inventaire de la bibliothèque de Pontus de Tyard (Geneva: Droz, 1950), p. 9.

${ }^{62}$ See the items listed in M. Connat \& J. Mégret 'Inventaire de la bibliothèque des Du Prat', at p. 119 . 
the presence of the same edition with different bindings shows the variation in resale value, with certain bindings doubling the original asking price. Przywilcki's books add a further layer of complexity as it is suggested that the prices given in the list followed those initially given by the bookbinder himself, rather than an appraiser's estimate. ${ }^{63}$

An interesting variation in this regard is provided by lists that contain price information added subsequently. The owner of the copy of the printed sales catalogue of Nicolaus Heinsius's library analysed by John Sibbald conscientiously annotated his volume with manuscript prices which he added in the margins. The interest of such a list is that the prices given are no longer an estimate attributed to the volume by an assessor but the amount of money actually paid for the book. And when this concerns over 13,00o items, such indications become particularly valuable. ${ }^{64}$

The example of the analysis of prices underlines the importance of accumulating as much contextual information as possible. It is essential to recognise that each list was drawn up in very specific circumstances. Even with the same genre, the same town and within the same period, volumes could be described in radically different ways. For instance, the variation in description of the inventories of the shops of sixteenth-century Krakow binders and publishers is particularly remarkable. ${ }^{65}$ Even when the Roman Congregation of the Index proceeded to have the holdings of the Italian clergy investigated in the late sixteenth century, the accuracy of the resulting data varied noticeably from one region to another. ${ }^{66}$ Much of the information provided in these lists can only be used when contextual elements are taken into account. The date at which the books were enumerated is obviously important: the political, religious and economic situation can be key to understanding correctly not only additional information, but also the strength and nature of censorship, for instance. The owner of the books, the compiler of the register and more generally anyone involved in the list's creation require study.

Geographic circumstances are equally important factors. The presence of trade routes can help explain the presence of certain imprints, or

63 Article 11: 'The Book Inventory of the Sixteenth-Century Krakow Bookbinder, Maciej Przywilcki'.

64 Article 6: 'The Heinsiana-Almost a Seventeenth-Century Universal Short Title Catalogue'.

65 Article 11: 'The Book Inventory of the Sixteenth-Century Krakow Bookbinder, Maciej Przywilcki'.

${ }^{66}$ Article 9: 'The Book Inventories of Servite Authors and the Survey of the Roman Congregation of the Index in Counter-Reformation Italy'. 
highlight a peculiarity of the list. For booksellers' and printers' holdings, the geographic location could determine the titles they stocked. This could vary enormously depending on the religious complexion of the region, the different judicial systems and the specific economic strengths of each town. This is particularly true when studying the book holdings of different people in the same region or town. The work of Andrea Ottone on the dioceses of southern Italy is particularly interesting in this regard. By analysing the volumes owned by the post-Tridentine secular clergy, he identifies interesting trends and demonstrates how book ownership reflected professional status. ${ }^{67}$

In this regard one should also be careful not to extract a book list from a wider inventory of belongings without providing some analysis of the other objects enumerated. The analysis of the volumes in isolation can lead the scholar to misunderstand the relative importance of the books to their owner. In probate assessments and, more generally, in inventories of the belongings of an individual or an institution, the context provided by the rest of the list can be the source of vital information. Here, Alex Marr's analysis of the books donated to the Bodleian offers a perfect illustration of this, where the books donated need to be considered in the wider framework of collections which also include numerous (and highly valued) mathematical instruments. ${ }^{68}$

\section{Identification of Editions}

Identifying the edition that corresponds to an item is perhaps the hardest part of editing a list. The wild variation in the quantity and quality of bibliographical data given by each list makes generalisations difficult. Often scholars are limited to the most basic information: the title and/or the author's name. However, in some cases the compiler chose to give some very precise information for every item listed. An extreme example of such scrupulous documentation is provided by the autobibliography of the sixteenth-century humanist Casper Brusch. In this instance, the author went as far as to include such elements as the number of leaves of each edition as well as often indicating the name of the dedicatees. ${ }^{69}$

67 Article 10: 'Pastoral Care and Cultural Accuracy: Book Collections of Secular Clergy in Three Southern Italian Dioceses'.

68 Article 2: 'Learned Benefaction: Science, Civility and Reconstructing Donations of Books and Instruments to the Bodleian Library Before 1605'.

69 Article 7: 'Printed Autobibliographies from the Sixteenth and Seventeenth Centuries'. 
Unfortunately such precision is rare. In most instances, scholars are left with the difficult task of extrapolating from incomplete descriptions. ${ }^{70}$

In the case of fifteenth-century lists, the limited number of existing editions can make identification more straightforward. But even here identification can be problematic. In their in-depth analysis of the sales journal of a Venetian bookseller active during the 1480s, Cristina Dondi and Neil Harris note that though determining the text used was simple enough, the seller generally only recorded the title. The only exceptions to this rule were texts of which they stocked more than one edition but, even in this case, when appropriate the compiler often simply resorted to indicating the format of the copy sold rather than adding more precise bibliographic data such as the name of the printer or the year of publication. The care and precision with which they have sought to analyse each entry in the list makes the appendix to their article a worthwhile template for future editions of book lists. ${ }^{71}$

However, providing such a sophisticated level of analysis can be problematic with later lists. Inevitably, the degree of difficulty varies with the amount of information provided in the original entries. Some lists give all the necessary indications including the name of the printer and the year in which the edition was produced, but others give virtually no information beyond the name of the author. Determining the edition in such cases often involves making an informed choice between a number of plausible possibilities. In certain instances the work is made even more difficult because of the misleading information that is given. In some of the entries described in the inventory of the holdings of Beatriz Pacheco's bookshop the most basic information, the name of the author and the title of the book, had been changed making it particularly difficult to trace first the original text and then the actual edition. ${ }^{72}$

Errors. One of the most difficult issues encountered in the analysis of book lists is recognising irregularities introduced by scribal mistakes.

70 For instance, the inventories of the library of San Marco in Venice (drawn up between 1622 and 1679) lack any typographical information: D. Raines, 'Dall'inventario 'short-title' al catalogo bibliografico: un excursus tipologico delle biblioteche private nella Venezia cinque-settecentesca' in F. Sabba (ed.), Le biblioteche private come paradigma bibliografico (Roma: Bulzoni, 2008) 79-95, pp. 92-93; and the catalogue of the books of the Congregation of St Maur in Rome of 1688, in F. Sabba, 'La biblioteca del 'Procureur général' della Congregazione di S. Mauro a Roma', ibidem, 235-254, Appendix pp. 247-254.

71 Article 14: 'Oil and Green Ginger. The Zornale of the Venetian Bookseller Francesco de Madiis, 1484-1488'.

72 Article 13: 'The Inventory of Beatriz Pacheco's Bookshop (Santiago De Compostela, $1563)^{\prime}$. 
This can sometimes make identification impossible and create editions that could not possibly have existed. In such cases a literal approach to the date information recorded in these manuscripts can lead to the strangest claims. In a recent study of the library of the Pontac, an historian was led to the impossible conclusion that a volume of Justinian supposedly printed in Paris in 1429 might have been the result of xylographic printing. Instead, he might have reflected that there was an edition published by the Parisian Claude Chevallon in 1529 and that the compiler had mistakenly replaced the five with a four. ${ }^{73}$ In Benito Rial Costas's work on the holdings of a Galician bookseller, he analyses the errors made in the probate inventory of her possessions and concludes that the document must have been drawn up by a scribe copying out titles that were dictated. ${ }^{74}$ The transition from spoken word to written inventory would inevitably lead to a number of misunderstandings. In such circumstances, even reputable printer-booksellers such as the Parisian Denis Duval would be prone to distort names and titles. ${ }^{75}$ In other cases, such as the catalogue of the books of the Breton jurist Bertrand d'Argentré, the mistakes would seem to have been the result of carelessness or weariness when copying out a draft document. ${ }^{76}$ Flavia Bruni in her study of the books owned by Servite authors suggests that such errors of transcription could also be attributed to insufficient levels of education amongst those who created the list. ${ }^{77}$

Title. The title is sometimes the only information given about a book, especially if the name of the author is not known. However, the manner in which this is rendered in the book list can be the source of some confusion. As has been noted by Shanti Graheli in her study of the publications of the Academia Venetiana, the title used in a list was not necessarily a verbatim reproduction of what is to be found on the title page of the original edition. In this case, the compiler of the list might well refer to a work by a keyword or a phrase which might be sufficient to enable identification of the text within the private context of a printer's workshop. ${ }^{78}$

73 C. Grenet-Delisle 'Une bibliothèque bordelaise au XVIIe siecle, la bibliothèque de Pontac' Revue française d'histoire du livre 132 (2011) 203-230 at p. 215. The Paris edition of the works of Justinian by Claude Chevallon contained 5 volumes, see FB 76133-4 \& 76136-8.

74 Article 13: 'The Inventory of Beatriz Pacheco's Bookshop (Santiago De Compostela, 1563)'. This idea was also put forward by Roger Doucet in his study of Parisian libraries (see his Bibliothèques parisiennes, p. 10).

75 See the examples given in J. Delatour, Une bibliothèque humaniste, pp. 50-1.

76 Article 5 'The Library of the Breton Jurist and Historian Bertrand d'Argentré in 1582 '.

77 Article 9: 'The Book Inventories of Servite Authors and the Survey of the Roman Congregation of the Index in Counter-Reformation Italy'.

78 Article 12: 'Reading the History of the Academia Venetiana Through its Book Lists'. 
More generally, it is common to find lists that use heavily abbreviated forms of the title or, indeed, lists where it has been replaced by the name of the author or a well-accepted variant. ${ }^{79}$

Printed and manuscript books. The question of the relationship between print and manuscript is another issue. In the catalogue of the books owned by Josephus-Justus Scaliger drawn up by Bonaventura Vulcanius there was a clear distinction made between the manuscripts (that were considered particularly valuable) and the printed items. ${ }^{80}$ However, this was rare. In most inventories manuscript items are listed alongside printed items. In lists with relatively little bibliographic information on each item, differentiating between the two can be difficult. In some cases, the compiler would introduce a helpful annotation such as "written by hand", but even in lists where this type of indication does appear, its absence for other items cannot be seen as proof that a title was printed. This is illustrated in Bertrand d'Argentré's list by the appearance of Le Baud's Brévière des Bretons. ${ }^{81}$ Even when both categories were clearly separated, one should treat the distinction made with a healthy amount of scepticism. Some of these books have a distinctly hybrid quality. Printed books with lavish hand painted miniatures or considerable marginalia could easily have been categorised as manuscripts and, indeed, often are even in modernday libraries. Similarly, composite volumes could easily contain both manuscript and printed items.

Place of printing and printer. The geographic location and identity of the collector are often used by scholars to identify where and by whom a book was printed when no relevant data has been included in the list. This is, however, a leap of faith. Editions produced in a distant print centre could easily have been shipped to the place in which the work was listed. Here the analysis of regional trade links and additional information about the bookselling culture of the town or region in which the collector lived could all be used to select the probable place of printing, but without any certainty. As has been noted for the case of Santiago, the tendency simply to identify entries in a book list with the most local edition only serves to increase the seemingly parochial nature of a collection without sufficient

79 It has been suggested that some titles could be taken from the books' spine, see F. Bruni 'La biblioteca di S. Pier Piccolo ad Arezzo: tracce per una ipotesi ricostruttiva' in R.M. Borraccini (ed.), Dalla notitia librorum degli inventari agli esemplari: saggi di indagine su libri e biblioteche dai codici Vaticani latini 11266-11326 (Macerata: Edizioni Università di Macerata, 2009), 179-203, at pp. 201-202.

80 Article 3: 'The Legacy of Scaliger in Leiden University Library Catalogues, 1609-1716'.

81 Article 5: 'The Library of the Breton Jurist and Historian Bertrand d'Argentré in 1582'. 
proof. The result can be to give a very misleading impression of the book culture of an individual or of an area. ${ }^{82}$

Dating. The erroneous reading or transcription of the date is one of the main sources of difficulty when attempting to identify an edition. Here, the comparison of book lists with surviving collections can be particularly informative. When the rest of the bibliographic data is of high quality, it also enables manifest mistakes to be corrected with some degree of certainty. In the case of the Roman Index lists where the data given includes the author's name, the title of the work, the place of printing and the name of the publishers, the historian has sufficient contextual information to correct an obvious error in the date of publication. ${ }^{83}$ One of the most typical mistakes is the misreading of a year expressed in Roman numerals. Another is to transcribe faithfully a date that was not the date at which the book was published but another date on the title page or inside the book.

Dates were not included as a matter of course in most book lists. They were often left out of otherwise quite precise probate inventories. ${ }^{84}$ When no date is given, the identification of the edition cited becomes particularly problematic. Historians have traditionally chosen to select the reprint of a text that is closest chronologically to the date of the list with which they are working. ${ }^{85}$ This, however, is generally not borne out by the lists that give sufficiently complete data. In the Pontac inventory of 1681 , for instance, over $88 \%$ of the collection was dated from before 1620 and the most common decade of publication was the 1580 - - a full century before the inventory of the library was drawn up. ${ }^{86}$ In some cases there might be additional, but vague indications that seem to have some bearing on the date at which a given edition was published. Thus, for instance, the compiler of the list might note that one item was an "old edition". However, this is not necessarily an indication of great age and might instead be a remark based on the use of an antiquated typeface or page layout. In mid to late sixteenth-century France, this might just mean that the edition was

82 Article 13: 'The Inventory of Beatriz Pacheco's Bookshop (Santiago De Compostela, $1563)^{\prime}$.

${ }^{83}$ See the illustrative cases provided in article 9: "The Book Inventories of Servite Authors and the Survey of the Roman Congregation of the Index in Counter-Reformation Italy'.

84 See the 1595 inventory of Dupuy's books (J. Delatour, Une bibliothèque humaniste) which consistently gives other information such as the format and a succinct description of the binding, but systematically omits the date.

85 See for instance the note included as a preamble to the inventories listed in Doucet, Bibliothèques parisiennes, p. 82.

86 This has been calculated using the figures given in Grenet-Delisle 'Une bibliothèque bordelaise', p. 216. 
printed in gothic type. It might also be a remark related more to the perceived value of the book than to the date of its publication: it seems unlikely, for instance, that an edition by the Aldine presses would be described in this way whatever its real age.

Language. Books in foreign languages posed a particular problem for the compilers of book lists. With books in the less widely studied ancient languages, such as Hebrew and Greek, it was relatively common for titles to be translated into either Latin or the local vernacular language without necessarily indicating the original language of the book. As has been noted in the case of Parisian probate inventories, one cannot even assume that a title given in Latin in the list would not actually have been a vernacular edition. ${ }^{87}$

With the difficulties set by the identification of editions and the numerous limitations that we have acknowledged, using book lists is clearly a complicated process. The opposition some historians have identified between qualitative and quantitative analysis of book lists can act as a further disincentive for those wishing to use them. ${ }^{88}$ In such circumstances, the enthusiasm demonstrated by early proponents of the use of book lists can seem misplaced. This has led Albert Derolez in his work on the catalogues of manuscripts in medieval libraries to conclude that it would be best just to identify the books cited and not attempt any further analysis. ${ }^{89}$ This seems very reductive. Jettisoning book lists as an historical source simply because their use is difficult makes little sense. Analysis can be more enterprising and yet simultaneously cautious, as was exemplified by the approach adopted by Jérôme Delatour who chose to grade his identifications of editions and copies as certain, probable, possible and unidentified. ${ }^{90}$

The articles that follow present a wide variety of book lists, drawn up at different points during the fifteenth, sixteenth and seventeenth centuries in a number of European cities. They demonstrate the extraordinary richness and complexity of the developing book world, in which books easily crossed national and linguistic boundaries to end up in collections very far from their place of publication. They show us confident owners, branching out from the narrow specialisms of the earliest collections

\footnotetext{
87 Doucet, Bibliothèques parisiennes, p. 11.

88 See the analysis of Benito Rial Costas in his 'Sixteenth-Century Private Book Inventories and Some Problems Related to their Analysis' Library and Information History, 26 (2010), pp. 70-82.

89 A. Derolez, Les catalogues de bibliothèques (Turnhout: Brepols, 1979), p. 67.

90 J. Delatour, Une bibliothèque humaniste, p. 110.
} 
painstakingly accumulated by lawyers, doctors and clerics for professional purposes, to encompass broad-ranging literary and cultural interest. They demonstrate a growing interest in the natural sciences, astrology and architecture, and an increasing willingness of publishers to undertake complex and technically demanding texts to satisfy this demand. And they demonstrate that the constant vigilance of authorities keen to define acceptable belief could not overwhelm a determined inquisitiveness of spirit among those building a library. Certainly, it is hoped that the studies included in this volume show how, when exercising due care, it is possible to use these lists to achieve a better understanding of the early modern book world. 